\title{
HAPPINESS AS A KEY FACTOR OF THE CREATIVE ECONOMY FOR SUSTAINABLE DEVELOPMENT
}

In Happiness And Contemporary Society : Conference Proceedings Volume (Lviv, March, 20-21, 2021). Lviv: SPOLOM, 2021. P. 118-123. https://doi.org/10.31108/7.2021.26

ISBN 978-966-919-697-2

ГОЛЯШ Ірина

\section{ЩАСТЯ ЯК КЛЮЧОВИЙ ЧИННИК КРЕАТИВНОЇ ЕКОНОМІКИ ДЛЯ СТАЛОГО РОЗВИТКУ}

// Щастя та сучасне суспільство : збірник матеріалів міжнародної наукової конференції (Львів, 20-21 березня 2021 р.). - Львів : СПОЛОМ, 2021. С. 118-123. https://doi.org/10.31108/7.2021.26

ISBN 978-966-919-697-2 
GOLYASH Iryna

PhD in Ecomonics, Associate Professor

The Ukrainian Institute for Happiness Research (Lviv, Ukraine)

\section{HAPPINESS AS A KEY FACTOR OF THE CREATIVE ECONOMY FOR SUSTAINABLE DEVELOPMENT}

People are the most important resource of the new era, and the creative economy and happiness are interdependent elements necessary for the balanced development of the economic, social and environmental spheres. By helping to achieve the Sustainable Development Goals, the creative economy influences living standards and provides a sense of happiness.

If people are positive and happy, then they are able to produce creative ideas and strive for an active life with an emphasis on achieving goals.

For the sake of profitability, the creative sectors of the economy constantly encourage people to be creative, but the ability to generate ideas is unstable, because everything depends on the state of man and the environment in which he lives and works.

Therefore, the main task of any country should be to ensure happiness for everyone, which is the basis for the existence of a creative economy. Otherwise, the country will automatically stop its development and begin to degrade rapidly.

Human happiness must be not only a key factor in the creative economy for sustainable development, but also a mission for the development of each country and society as a whole.

KEY WORDS: Creative economy, Happiness, Sustainable Development Goals.

ГОЛЯШ Ірина

кандидат економічних наук, доцент

Украӥнський інститут дослідження щастя (Львів, Україна)

\section{ЩАСТЯ ЯК КЛЮЧОВИЙ ЧИННИК КРЕАТИВНОЇ ЕКОНОМІКИ ДЛЯ СТАЛОГО РОЗВИТКУ}

Креативна економіка у XXI столітті має величезний потенціал впливу на соціально-економічний розвиток та прискорене інноваційне оновлення сучасного світу. В основі креативної економіки лежить здатність людини нестандартними способами вирішувати існуючі й потенційні проблеми та впливати на покращення життя майбутніх поколінь в контексті викликів, зумовлених четвертою промисловою революцією.

Враховуючи гостру необхідність вирішення проблем людства, Генеральною Асамблеєю ООН було прийнято резолюцію, яка закликає всі країни докласти зусиль щодо підтримки креативної економіки з метою сталого розвитку, a 2021p. оголошено Міжнародним роком креативної економіки [1, с.1].

Термін «креативна економіка» набув популярності ще у

2001p. завдяки британському письменнику, члену Консультаційної ради по 
креативній економіці ООН, Дж. Хокінсу, який сформував концепцію економічної системи, в якій цінність залежить від оригінальності та креативності, а не від традиційних ресурсів [2].

У такій системі відбувається трансформація від раціональності «економічної людини» («homo economicus») до постраціональності, що зорієнтована на креативну діяльність та саморозвиток «креативної людини» («homo creator»). [3, c. 234].

Основою креативної економіки є творчість та ідеї, які створені «hото creator» $[4$, c. 54-55]. Креативну людину дослідники визначають як особистість 3 творчими здібностями, які охоплюють дії від нестандартного розв'язку простого завдання до нової реалізації унікальних потенцій індивіда в певній галузі, в результаті чого з'являються нові напрямки розвитку, виробляються нові продукти (послуги), створюються нові процеси, знаходяться нові шляхи та навіть нові сенси людського життя й суспільного розвитку. В характері креативних людей домінує відвертість, сприйнятливість, ініціативність, здатність володіти ситуацією та самостійно здійснювати пошук способів вирішення проблем і досягнення цілей. На противагу цьому, люди, які не проявляють ознак креативності, у своїй поведінці $\epsilon$ подавленими, незадоволеними, керованими, що діють за командою чи зі страху, мають обмежений кругозір й завжди знаходять певні причини та оправдання стосовно неможливості вирішення проблем та досягнення цілей, окрім того, вони обтяжені власними установками та не є щасливими [5, с. 4-8].

Отже, креативними можуть бути лише ті люди, які позитивно налаштовані та щасливі. Вони, з однієї сторони, здатні до генерування креативних ідей, а з іншої - націлені на активне життя з акцентом на досягнення цілей.

Зазначимо, що творчі здібності від людини відділити не можна, так само, як i не можна їх купити, продати, вкрасти, позичити тощо. Однак, можна підтримати здатність людини до креативності, або ж стимулювати іiі спроможність до генерування нестандартних ідей. Для цього слід забезпечити комфортність середовища, в якому ця людина живе та працює, оскільки працездатність «homo creator» залежить від позитивного настрою та можливості перебування в стані «потоку» - стані повного єднання з діяльністю та ситуацією.

Нові творчі ідеї, а не гроші, чи технології приносять сьогодні особисте задоволення людей та мають вирішальний вплив на зростання $\mathrm{i}$ розвиток найуспішніших компаній світу [2]. Нове покоління креативних людей прагне бути щасливим, захопленим і прагне зробити світ навколо себе інтуїтивно зрозумілим. У цьому сенсі креативна економіка $є$ економікою майбутнього [6].

Головною особливістю креативної економіки є ефективне та збалансоване поєднання процесів генерування креативних ідей та отримання прибутку від їх реалізації. Задля прибутковості креативні сектори економіки постійно підштовхують людей до творчої активності, однак, здатність до генерування ідей $\epsilon$ нестійкою, оскільки вона залежить від стану людини та середовища, в якому ця людина живе та працює. Тому творчість не може вважатися товаром.

Рушійною силою креативної економіки $є$ щасливі люди, бо вони здатні:

- виробляти креативні ідеї, без яких креативна економіка існувати не може;

- створювати (удосконалювати, перетворювати, змінювати тощо) креативні продукти (послуги), задовольняючи при цьому власні потреби та потреби інших людей. 
Задовольняючи свої потреби, люди стають більш щасливими [7]. Згідно концепції А. Маслоу, спершу задовольняються базові фізіологічні потреби, потім потреби самозбереження, далі - потреби спілкування і спільної діяльності, після цього потреби досягнення успіху і визнання. I наостанок - потреби, пов'язані з реалізацією здібностей, творчістю, досягненнями власних цілей (див.рис.1). Від першого рівня до п'ятого відбувається поступове віддалення від матеріальних потреб та наближення до духовних потреб. Особливою ознакою «homo creaton» $є$ відмова від максимізації матеріального добробуту на користь розвитку потреб найвищого рівня.

Зазначимо, що «homo creator» присутні в усіх секторах економіки та виступають суб'єктами їі процесів. У креативній економіці всі процеси можна охарактеризувати як «шлях від щастя і до щастя», що обумовлено такими обставинами:

- по-перше, креативні ідеї продукуються лише позитивно налаштованими та щасливими людьми [5];

- по-друге, мозкові структури людей реагують на виникнення креативних ідей, внаслідок чого з'являється почуття задоволення, а стабільне задоволення створює відчуття щастя [7];

- по-третє, чим більш щасливим стає мозок, тим більш людина стає креативною, продуктивною i відкритою до нових ідей (доведено що позитивно налаштований мозок на $31 \%$ продуктивніший, аніж мозок у негативному, нейтральному або напруженому стані) [7];

- по-четверте, у креативній економіці не лише генерування ідей, але й вся творча робота $\epsilon$ атрибутом самореалізації сучасної особистості, критерієм, який звеличує людину, робить її щасливою [4];

- по-п'яте, реалізація креативних ідей здатна задовольнити потреби інших людей, колективу, нації та суспільства, покращити їх життя та зробити щасливими.

Таким чином, творчу діяльність «homo creator» можна вважати невичерпним джерелом людського щастя.

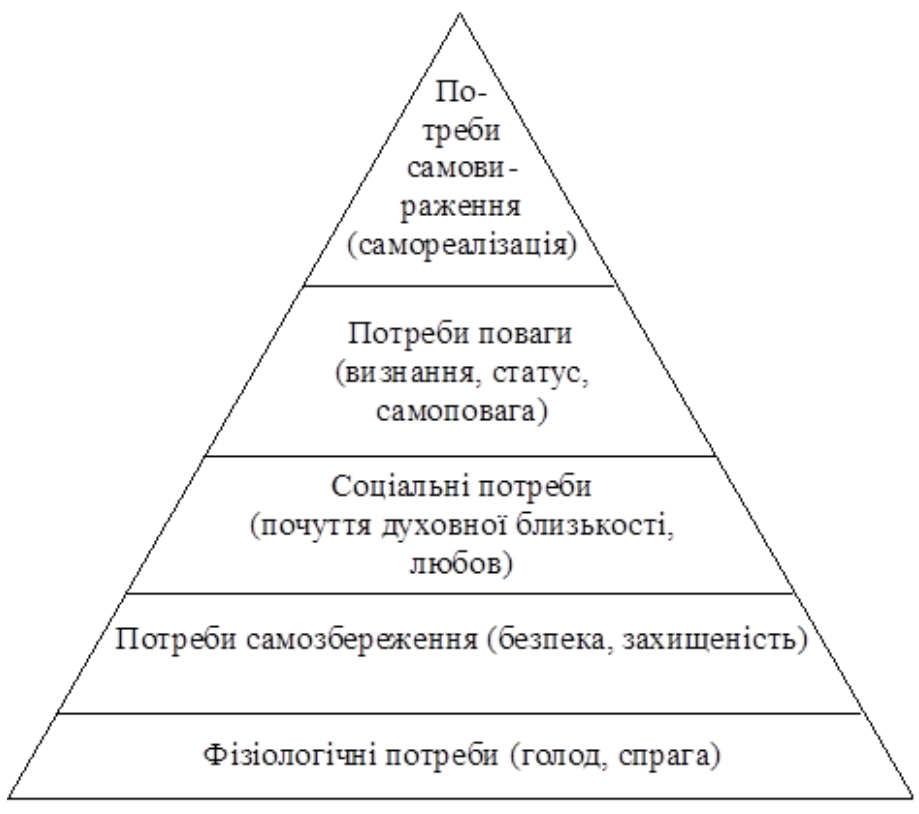

Рис.1 Піраміда потреб А.Маслоу 
Задоволення потреб супроводжує весь процес життєдіяльності людини, колективу, нації та суспільства, однак, потреби не є постійними - їх характер, структура і способи задоволення залежить від досягнутого рівня продуктивних сил, ступеня розвитку культури і науки, соціально-економічного ладу [8, с.88-92]. У кожному суспільстві діє закон зростання потреб, а тому завданням креативної економіки повинно стати нетрадиційне вирішення проблем, пов'язаних iз збереженням, відтворенням та раціональним використанням наявних благ, оскільки блага існують в обмеженій кількості у порівнянні з потребами, які вони задовольняють.

Знання в креативній економіці мають бути спрямовані на раціональне використання й заміщення певних ресурсів, зокрема матеріалів, енергії, робочого часу, простору тощо. Таким чином, людина впливає на трансформацію матеріального ресурсу в нематеріальний, адже знання і креативність мислення дають змогу ефективніше використовувати наявні блага й прогресивно створювати нові [9, с.55-60].

Креативна економіка сприяє сталому розвитку, впливаючи на економічне зростання та інноваційну діяльність, подолання бідності, забезпечення повної і продуктивної зайнятості та гідної роботи для всіх, підвищення якості життя, розширення прав і можливостей жінок та молоді, зменшення нерівності між багатими всередині країн та між ними тощо. Таким чином, креативна економіка впливає на досягнення Цілей сталого розвитку (ЦСР) на період до 2030 року зокрема, шляхом:

- зменшення вразливості населення до бідності за рахунок розвитку креативного сектору економіки (ЦСР 1);

- впровадження креативних методів ведення сільського господарства для підвищення життєстійкості та продуктивності, збільшення обсягів виробництва та сприяння збереженню екосистем (ЦСР 2);

- винайдення нових способів профілактики і лікування, а також підтримки психічного здоров'я і благополуччя (ЦСР 3);

- поширення знань і навичок, необхідних для підприємницької діяльності в креативній економіці (ЦСР 4);

- полегшення праці 3 догляду за дітьми й роботу 3 ведення домашнього господарства за рахунок використання в цих сферах інноваційних ідей, розширення прав і можливостей жінок (ЦСР 5);

- винайдення нових способів очищення та підвищення якості води та ефективності їі використання (ЦСР 6);

- збільшення частки енергії з відновлюваних джерел та модернізації технологій для сучасного енергопостачання (ЦСР 7);

- скорочення частки молоді, яка не працюе і не навчається за рахунок іiі залучення в креативні сектори економіки (ЦСР 8);

- сприяння розвитку інноваційної екосистеми (ЦСР 9);

- зменшення економічної нерівності за рахунок розвитку сфер креативної економіки (ЦСР 10); 
- забезпечення реалізації стратегій місцевого розвитку, спрямованих на економічне зростання, створення робочих місць, розвиток туризму, рекреації, місцевої культури і виробництво місцевої продукції (ЦСР 11);

- зменшення антропогенного навантаження на навколишне природне середовище за рахунок використання креативних ідей (ЦСР 12);

- пом'якшення гостроти та послаблення наслідків зміни клімату, підвищення опірності і здатності адаптуватися до небезпечних кліматичних явищ i стихійних лих новими способами (ЦСР 13);

- пошуку методів для відновлення та забезпечення сталого екологічного стану й продуктивності океанів (ЦСР 14);

- захисту та відновлення екосистем суші, сприяння їх раціональному використанню інноваційними методами (ЦСР 15);

- розробки нових шляхів побудови миролюбного й відкритого суспільства в інтересах сталого розвитку (ЦСР 16);

- інвестування в креативний сектор економіки (ЦСР 17) [10].

За рахунок сприяння досягненню Цілей сталого розвитку, креативна економіка впливає на підвищення рівня людського життя і забезпечує відчуття щастя $[11$, с.38].

Виходячи 3 цього, зробимо висновок про те, що креативні люди $\epsilon$ важливим ресурсом нової епохи, a креативна економіка $\mathrm{i}$ щастя $\epsilon$ взаємообумовленими елементами, які необхідні для збалансованого розвитку економічного, соціального та екологічного компонентів сталого розвитку.

Тому основним завданням будь-якої країни повинно стати забезпечення щастя для кожної людини, яке є основою існування креативної економіки. В протилежному випадку, країну очікує зупинка розвитку і швидка деградація [12, c.2]. Отже, щастя людини повинно бути ключовим чинником креативної економіки для сталого розвитку та місією розвитку кожної країни загалом.

\section{ЛITЕРАТУРА}

1. Матеріали Генеральної Асамблеї ООН. - [Електронний ресурс]. / Режим доступу: https://undocs.org/pdf?symbol=ru/A/C.2/74/L.16

2. Хокинс Дж. Креативная экономика. Как превратить идеи в деньги / перевод с англ. И. Щербаковой. - М.: Классика-XXI, 2011. - 256 с.

3. Поснова Т. В. Роль креативного людського капіталу в економіці знань / Т.В. Поснова// Електронне наукове фахове видання з економічних наук «Modern Economics». - №14. - 2019. - C. 232-236.

4. Грекова В. С. Ното creator: грані творчості / В. С. Грекова // Грані. - 2014. - № 11. - C. 53-57.

5. Микалко М. Рисовый штурм и еще 21 способ мыслить нестандартно / М. Микалко // «Манн, Иванов и Фербер (МИФ)». - Москва. - 2006.

6. Рагнар Сіiл Креативність - це феномен відкритого світу мобільних людей. [Електронний ресурс]. / Режим доступу: http://creativecountry.org/ragnar-siil/

7. Чому щасливі люди більш успішні. - [Електронний ресурс]. / Режим доступу: https://life.nv.ua/ukr/blogs/chomu-shchaslivi-ljudi-bilsh-uspishni-avstralijskijprofesor-213928.html 
8. Голяш І.Д. Досягнення щастя в рамках концепції сталого розвитку / І. Голяш // Матеріали I Міжнародної наукової конференції «Щастя та сучасне суспільство». - Львів. - 2020. - С.88-92.

9. Яцунь О. М. Креативний людський капітал в просторі суспільства знань: економічний аспект. Соціально-трудові відносини: теорія та практика. - 2014. - № 2. - C. 55-60.

10. Transforming our world: the 2030 Agenda for Sustainable Development: Resolution adopted by the General Assembly on 25 September 2015. - [Електронний ресурс].

Режим

доступу:

http://www.mfa.gr/images/docs/pagkosmia zitimata/resolution sdgs.pdf

11. Wilson N. Re-thinking Inclusive and Sustainable Growth for the Creative Economy: A Literature Review / N. Wilson, J. Gross, T. Dent, B. Conor, R. Comunian // Report DISCE. $-2020 .-73 \mathrm{c}$.

12. Жарінова А.Г. Економіка знань: зміст та роль інтелекту людини в іiі формуванні. - [Електронний ресурс]. / Режим доступу: http://jrnl.nau.edu.ua/index.php/PPEI/article/viewFile/222/218 